\title{
Pemanfaatan Biometrics Fingerprint sensor dan Barcode sensor pada Sistem Keamanan Parkir
}

\author{
Rhegiyana Pramudia Pahrudin ${ }^{1}$, Rahmat Hidayat ${ }^{2}$, Ulinnuha Latifa ${ }^{3}$ \\ 1,2,3 Universitas Singaperbangsa Karawang \\ 1,2,3 Jl. HS.Ronggo Waluyo, Puseurjaya, Kec. Telukjambe Tim., Kabupaten Karawang, Jawa Barat 41361 \\ rhegipp@gmail.com ${ }^{1}$,Rahmat.hidayat@staff.unsika.ac.id ${ }^{2}$, Ulinuha.latifa@ft.unsika.ac.id ${ }^{3}$
}

\section{ARTICLE INFO}

Article history:

\begin{abstract}
The development of science and technology is increasingly advanced, especially in the field of electrical technology or electronic technology, many advantages will be obtained from the development of technology, but the more technology develops, the more criminal acts and the smarter the criminals, especially in vehicle theft. We need a safe parking area to store our vehicles, increased safety must be considered in designing a parking security system. The system is expected to reduce the crime rate around us. This parking system design uses fingerprint sensor technology and a barcode scanner. Not only is the security system strengthened, but this tool can also provide personal data and vehicle information that is displayed on the LCD by combining the driver's fingerprint data. By using a continuous fingerprint system with a barcode scanner, it is hoped that it will reduce the risk of theft of vehicles in the parking area. The method of combining fingerprint sensors and barcode scanners is to use an Arduino Wemos D1 R1 microcontroller which is connected to the internet.
\end{abstract}

Keywords: Parking, Fingerprint Sensor, Barcode Scanner, Arduino Wemos D

\footnotetext{
Abstrak

Perkembangan ilmu pengetahuan dan teknologi semakin maju terutama dibidang teknologi elektro atau teknologi elektronika, banyak keuntungan yang didapatkan akan berkembangnya suatu teknologi namun semakin berkembangnya teknologi makin banyak pula tindak kriminal dan semakin pintar pula pelaku kriminal terutama pada pencurian kendaran. Kita membutuhkan lahan parkir yang aman untuk menyimpan kendaraan kita, peningkatan kemaanan merupakan salah satu yang harus diperhatikan dalam membuat perancangan sistem keamanan parkir. Sistem tersebut diharapkan menurangi tingkat kriminal yang ada disekitar kita. Perancangan sistem parkir ini menggunakan teknologi fingerprint sensor dan Barcode scanner. Bukan hanya sistem keamanan yang di perkuat alat ini pun dapat memberikan informasi data diri dan informasi kendaraan yang di tampilkan pada LCD dengan menggabungkan data sidik jari pengendara. Dengan menggunakan sistem fingerprint yang berkesinambungan dengan barcode scanner diharapkan menekan resiko pencurian kendaraan yang berada pada lingkungan parkir. Metode menyatukan Fingerprint sensor dan barcode scanner yaitu menggunakan mikrokontroler Arduino Wemos D1 R1 yang terkoneksi dengan internet.
} 


\section{PENDAHULUAN}

Saat ini, teknologi otomatis atau sistem pintar dikembangkan untuk memenuhi kebutuhan manusia, salah satunya adalah di bidang transportasi untuk keamanan dan kenyamanan sistem parkir kendaraan khusus. Sistem parkir yang dimaksud adalah bagi pengguna kendaraan yang ditempatkan pada tempat tertentu, contohnya sistem parkir di apartemen atau instansi tertentu. [1] dalam contoh intasi tersebut dengan ini manusia membutuhkan sistem parkir yang efektif dan otomatis

Salah satu aspek dalam sistem parkir otomatis adalah identifikasi objek untuk mendapatkan informasi dan memasukan data itu langsung ke sistem komputer tanpa keterlibatan manusia. Jenis objek yang diidentifikasi adalah sidik jari tangan. Fingerprint atau sensor sidik jari adalah salah satu perkembangan teknologi yang memiliki keamanan yang cukup tinggi dimana hanya bisa diakses oleh orang yang sidik jarinya sudah di input kedalam fingerprint. Dengan makin berkembangnya teknologi, makin banyak pula tindak kriminal diantaranya pencurian. Terlebih saat ini, pencurian kendaraan bermotor yang dikenal dengan curanmor menempati tempat teratas tindakan kriminal saat ini. Oleh karena itu, harus dibuat sebuah sistem pengaman pada kendaraan bermotor untuk menghindari hal-hal yang tidak diinginkan.[2]

Permasalahan lain yang ada pada sistem parkir adalah adanya pengecekan STNK oleh satpam pada tempat parkir didalam Universitas. Dengan adanya sistem ini satpam dapat memonitoring area parkir dalam smartphone atau dalam link aplikasi. Ini memudahkan pekerjaan satpam jika ada suatu kejadian kehilangan kendaraan, didalam aplikasi terdapat data masuk dan keluar pemilik kendaraan. Aplikasi Odoo sangat tepat untuk menyelesaikan permasalahan pengelolaan data yang masih manual.[3]

Bukan hanya menggunakan teknologi biometric pembangunan sistem parkir yang baik dapat digabungkan dengan berbagai teknologi salah satu contohnya Barcode Sensor. Penggunaan Barcode sensor disini memberikan suatu keuntungan seperti pembacaan data dengan contoh memberikan data suatu kendaraan pada Barcode dengan data yang unik dan berbeda satu dengan yang lainnya. Dengan kata lain pemanfaatan kedua teknologi tersebut sebagai verifikasi keamanan dua langkah dengan Barcode bekerja sebagai metode pengamanan dengan pengenalan data kendaraan dan Fingerprint bekerja sebagai metode pengamanan pembacaan sidik jari pengguna kendaraan.

Adapun tujuan yang ingin dicapai pada penelitian ini antara lain:

1. Mengurangi angka curanmor diarea parkir, membuat hanya pemilik kendaraan yang terdaftar sebelumnya yang bisa masuk kedalam area parkir.

2. Memanfaatkan keunikan pola sidik jari dan pola batang barcode untuk divalidasi dalam sistem keamanan.

3. Dengan adanya monitoring sistem area parkir di aplikasi dan membuat satpam dapat melihat kepemilikan kendaraaan dan tidak harus menujukan STNK yang dapat membuat antrean jika dijam padat.

\section{TINJAUAN PUSTAKA}

\subsection{Sidik Jari}

Sidik jari adalah satu ciri-ciri fisik manusia yang bersifat unik, artinya diciptakan berbeda dengan individu lainnya. Sidik jari manusia diibaratkan seperti pola bukit dan lembah yang tercipta supaya lebih mudah untuk mencekram sesuatu, sama seperti pola tapak ban yang berperan untuk mendapat grip atau cengkraman dijalan aspal. Kode genetik pada DNA memberikan informasi bagaimana kulit halus terbentuk ketika masih janin. Kulit bagian telaoak kaki mulai tumist sampai ujung jari yang mana pada daerah tersebut terdapat garishalus menonjol yang keluar satu sama lain yang dipisahkan oleh celah atau a;ur yang membentuk struktur tertentu. Sidik jari setiap orang mempunyai perbedaan baik pada orang kembar sekalipun[4]. Dengan ini membuat pola pada sidik jari dapat digunakan pada teknologi keamanan biometrik.

\subsection{Fingerprint sensor FPM10A}

Fingerprint merupakan salah satu sensor sidik jari yang umum digunakan. Sistem kerja dari fingerprint yaitu mengambil gambar sidik jari pengguna dan menentukan keputusan mengenai kesamaan pola sidik jari antara gambar yang diambil dengan pola yang sudah tersimpah dalam database. Optical scanning merupakan salah satu metode yang sering digunakan untuk mengambil gambar sidik jari seseorang. Proses

Pemanfaatan Biometrics Fingerprint Sensor dan Barcode Sensor pada sistem Keaman Parkir 
scan mulai berlangsung ketika sesorang meletakkan jarinya pada lempengan kaca dan kamera CCD (Charge Coupled Device) mengambil gambarnya. Cahaya yang biasa digunakan pada scanner yaitu berupa larik LED (light emitting diodes), cahaya tersebut berguna untuk menyinari alur dari sidik jari. Hasil gambar dari sistem CCD yaitu berupa jari yang terbalik, dimana jika cahaya yang dipantulkan (bagian punggung dari alur sidik jari) lebih banyak menunjukkan area yang lebih gelap dan jika cahaya yang dipantulkan (bagian lembah dari alur sidik jari) lebih sedikit menunjukkan area yang lebih terang.[5]

\subsection{Barcode sensor}

Barcode merupakan simbol yang dibaca oleh alat scanner, guna memudahkan pemasukan data secara otomatis ke komputer. Barcode terdiri dari deretan spasi dan garis-garis tegak lurus dengan jenis ketebalan dimensi serta kepekatan warna yang berbeda yang diartikan sebagai satu deretan karakter.[6] Barcode menggunakan urutan garis batang vertikal dan jarak antar garis untuk mewakili angka atau simbol lainnya. Dengan demikian, setiap ketebalan garis batang dan jarak antara garis saru dengan yang lain selalu berbeda sesuai dengan isi data yang dikandung oleh kode batang atau barcode tersebut. Kode batang ini akan didideteksi atau discan oleh barcode scanner.[7]

\subsection{Arduino Wemos D1 R1}

WeMos merupakan salah satu Arduino compatible development board yang dirancang khusus untuk keperluan IoT (Internet of Thing). WeMos menggunakan chip SoC WiFi yang cukup terkenal saat ini yaitu ESP8266. Cukup banyak modul WiFi yang menggunakan SoC ESP8266. [8] Kelebihan dari Wemos D1 R1 ini adalah bersifat open source, kompatibel dengan Arduino, dapat deprogram menggunakan Arduino IDE, pinout yang kompatibel dengan Arduino Uno, dapat berdiri sendiri tanpa menggunakan mikrokontroler lain, memiliki prosesor 32-bit dengan kecepatan $80 \mathrm{MHz}$, High Level Language, bisa deprogram dengan bahasa pemograman Phyton dan Lua. [9]

\subsection{Odoo}

Odoo merupakan salah satu Enterptise Resource Planning (ERP) yang dibuat dengan menggunakan bahasa pemograman Phyton dan bersifat Open Source. Odoo merupakan versi 8 dari aplikasi Odoo. Odoo berganti nama menjadi Odoo karena pada Odoo ERP sudah terdapat beberapa fitur tambahan yang tidak terdapat pada cakupan ERP. Odoo di bangun menggunakan teknologi framework open object yang memiliki kekuatan fitur MVC (Model View Controller), workflow atau alur kerja proses yang fleksibel, GUI yang dinamis, dan sistem pelaporan yang dapat dikostumisasi sesuai dengan kebutuhan bisnis.[10] Sistem ERP ini tidak hanya dapat menggunakan jaringan intranet saja akan tetapi jaringanya sudah bisa terkoneksi internet sehingga memudahkan bagi user untuk melakukan penginputan data , pengolahan, dan pembuatan ouput yang berupa laporan dapat dilakukan secara online.[3]

\section{METODOLOGI PENELITIAN}

Metode penelitian dalam perancangan pemanfaatan fingerprint sensor dan barcode sensor adalah sebagai berikut:

1. Studi Literatur

Pada metode ini penulis mempelajari dan membaca berbagai referensi dari arsip-arsip jurnal yang relevan dengan masalah yang akan dibahas serta landasan teori yang mendukung sebagai acuan dalam melakukan perencanaan percobaan dan penyusunan laporan.

2. Identifkasi kebutuhan

Berdasarkan data dilapangan dapat dituliskan kebutuhan dalam area parkir di lingkungan pendidikan antara lain :

- $\quad$ Sistem parkir masih manual

- $\quad$ Tingkat keamanan yang rendah

- Tidak adanya data kepemilikan kendaraan

- Tidak ada riwayat masuk dan keluarnya kendaraan

Dengan data diatas yang dibutuhkan dalam sistem parkir untuk mengatasi kebutuhan diatas antara lain :

- $\quad$ Sistem parkir otomatis

- Meningkatkan kemanan

- Mendapatkan data kepemilika kendaraan

- Mendapatkan informasi riwayat keluar dan masuknya kendaraan

3. Perancangan dan Pengembangan alat

Pemanfaatan Biometrics Fingerprint Sensor dan Barcode Sensor pada sistem Keaman Parkir 
Metode ini untuk membentuk perancangan sistem alat yang tepat sehingga menghasilkan rancangan yang sesuai dengan analisa kebutuhan yang diinginkan. Skema perancangan sistem ditunjukan pada gambar di bawah ini:

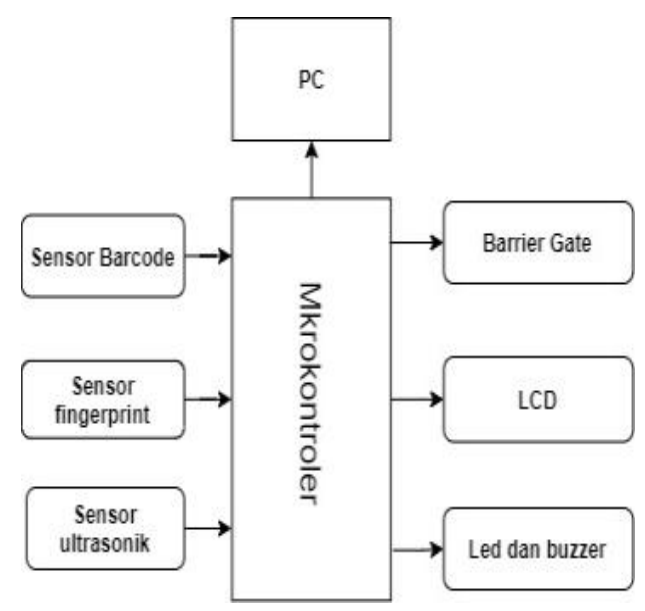

Gambar 1. Diagram blok sistem

Pada gambar 1 di atas menjelaskan input dan output dalam sistem ini, diperlihatkan bahwa inputan sistem ini ada 3 yaitu fingerprint sensor, barcode scanner, dan sensor ultrasonik lalu ada pun output sistem ini sebagai berikut barier gate, LCD, buzzer dan lampu LED. Semua input dan output mengirim sinyal ke suatu kendali atau otak yaitu mikrokontroler Wemos d1 r1.

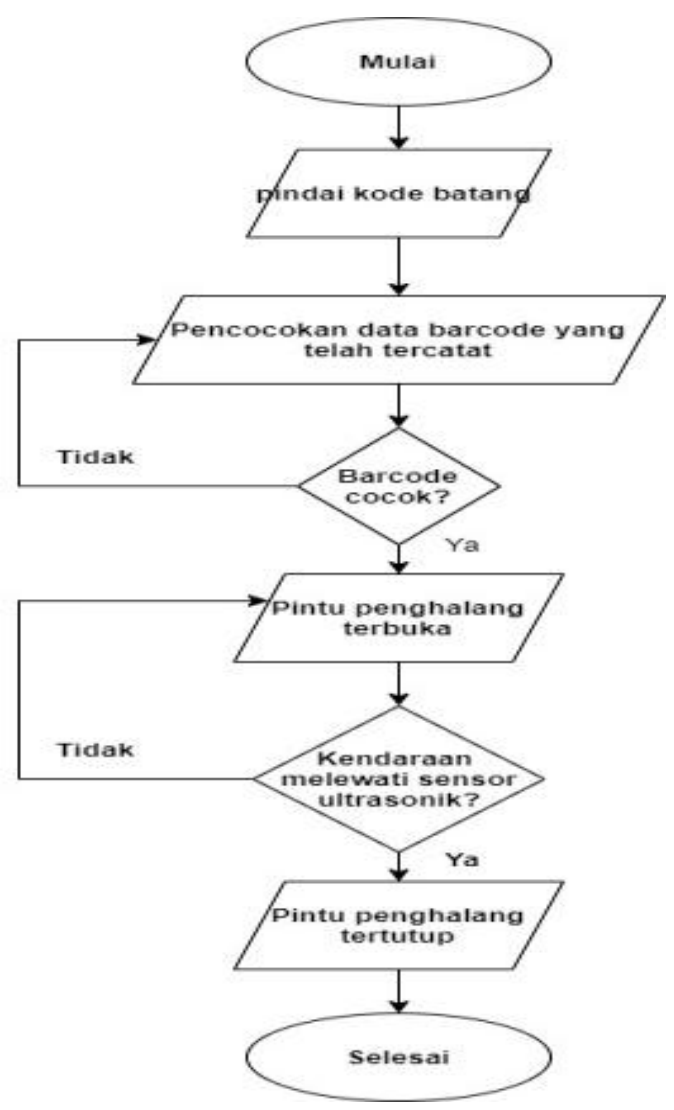

Gambar 2. Flowchart Sistem Masuk

Pemanfaatan Biometrics Fingerprint Sensor dan Barcode Sensor pada sistem Keaman Parkir 
Berdasarkan gambar 2 pada saat pengendara memasuki parkiran. Disini pengendara memindai kode batang ke barcodescanner untuk membuka palang pintu sekaligus akan mengirimkan data pengendara dan penambahan jumlah kendaraan yang masuk kedalam aplikasi. Indikator LCD akan menujukan data pengendara dan lampu akan menyala mendakan pengendara dapat memasuki parkiran. Setelah pengendara melewati palang pintu sensor ultrasonik akan mendeteksi apakah kendaraan sudah melewatinya atau belum jika kendaraan telah dideteksi maka sensor akan mengirim sinyal untuk menutup palang pintu.

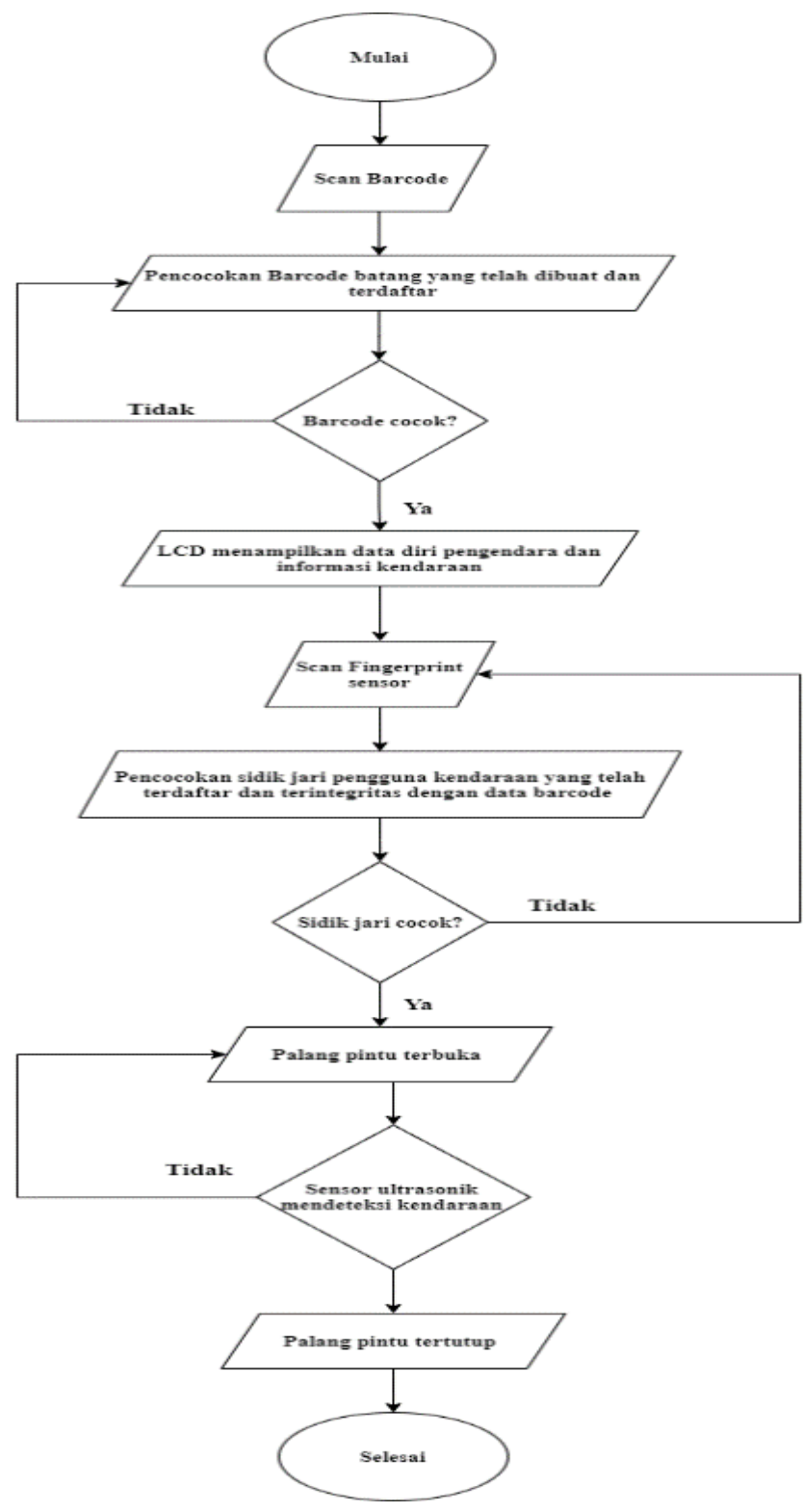

Gambar 3. Flowchart Sistem keluar

Berdasarkan gambar 3 diatas yaitu proses pengendara saat akan menggunakan sistem, dengan dimulainya pengendara memindai kartu yang terdapat kode batang barcode untuk memvalidasi awal kendaraan yang dibawa apkah sudah terdaftar dalam sistem. Setelah barcode membaca dan hasilnya akan muncul pada layar lcd jika dinyatakan terdaftar selanjutnya pengendara akan memindai sidik jari untuk validasi kedua bahwa kode barcode pengendara cocok dengan sidik jari pemilik kendaraan jika teridentifikasi cocok maka palang pintu akan terbuka dan pengendara bisa masuk atau keluar setelah pengendara keluar sensor ultrasonik akan mendeteksi dan palang pintu akan tertutup.

Pemanfaatan Biometrics Fingerprint Sensor dan Barcode Sensor pada sistem Keaman Parkir 
Data pengendara akan disimpan di aplikasi server di dalam database, di dalam database akan terlihat waktu pengendara masuk dan keluar, data kendaraanpun akan terlihat seperti nomer mesin kendaraan sampai dengan alamat pengendara.

Komponen dalam flowchart yang digunakan pada sistem parkir BIOPARKS akan dihubungkan kedalam satu wiring system berikut :

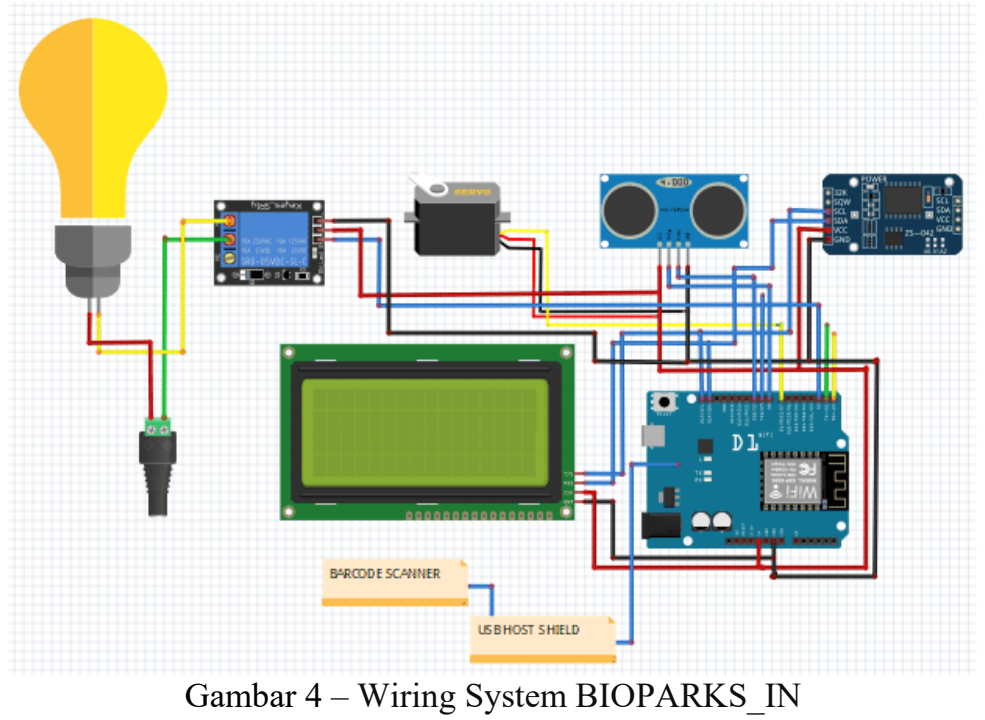

Berdasarkan gambar 4 diatas menunjukan wiring system BIOPARKS masuk kedalam area parkir yang mengahruskan pengendara menscan barcode. Pada gambar 5 di bawah ini menunjukan wiring system keluar dari sistem parkir BIOPARKS.

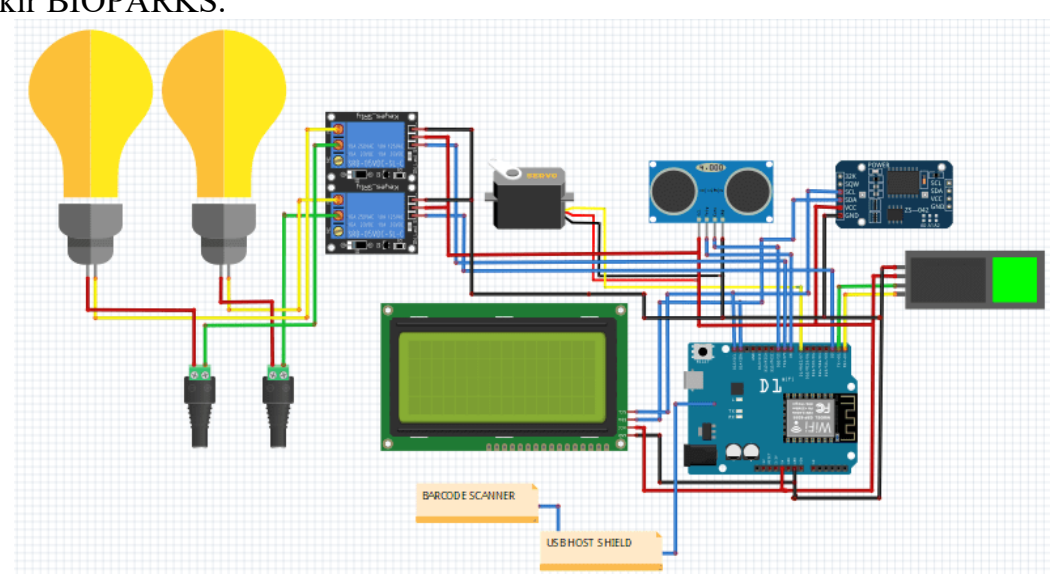

Gambar 5 - Wiring System BIOPARKS_OUT

Pada gambar 5 menunjukan wiring system BIOPARKS keluar dimana kendaraan yang dan pengendara yang telah berada di dalama area parkir harus menscan kembali barcode kendaraan setelah sesuai pengendara wajib menscan sidik jari dan jika sesuai maka pengendara bisa keluar dari area parkir. Untuk melihat desain hardware dari sistem parkir BIOPARKS dapat dilihat pada gambar 6 di bawah ini.

Pemanfaatan Biometrics Fingerprint Sensor dan Barcode Sensor pada sistem Keaman Parkir 
41

p-ISSN: 1907-0012 e-ISSN : 2714-5417
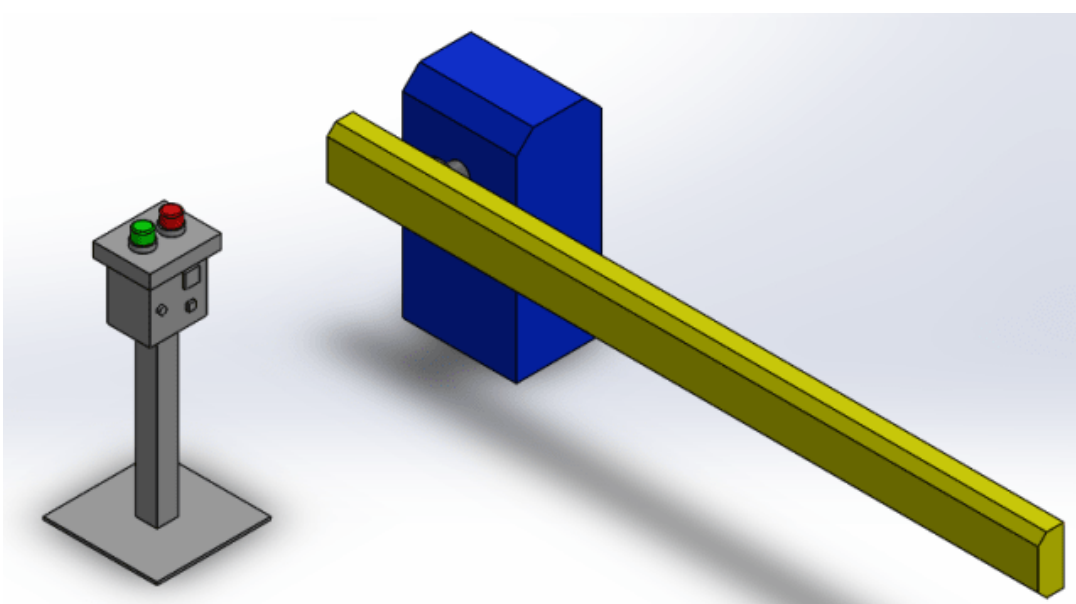

Gambar 6 - Desain Hardware Produk BIOPARKS

Pada gambar 6 menujukan desain hardware dari produk BIOPARKS. Desain Hardware pada produk BIOPARKS terdapat beberapa fitur seperti mampu mengetahui adanya indikasi pencurian, mengetahui data masuk dan keluar kendaraan yang melakukan parkir dan dapat melakukan identifikasi karakteristik pada seseorang.

\section{HASIL DAN PEMBAHASAN}

\subsection{Pengujian Alat}

Hasil perancangan alat ini dengan nama BIOPARKS (Biometric Parking System) dalam hasilnya dilakukan pengujian BIOPARKS. Pengujian dilakukan bertujuan untuk mengetahui kinerja sistem yang telah dibuat. Pengujian dilakukan dalam masing-masing sistem dan dapat menampilkan hasil yang sesuai dengan diharapkan,

1. Pengujian sistem parkir saat masuk

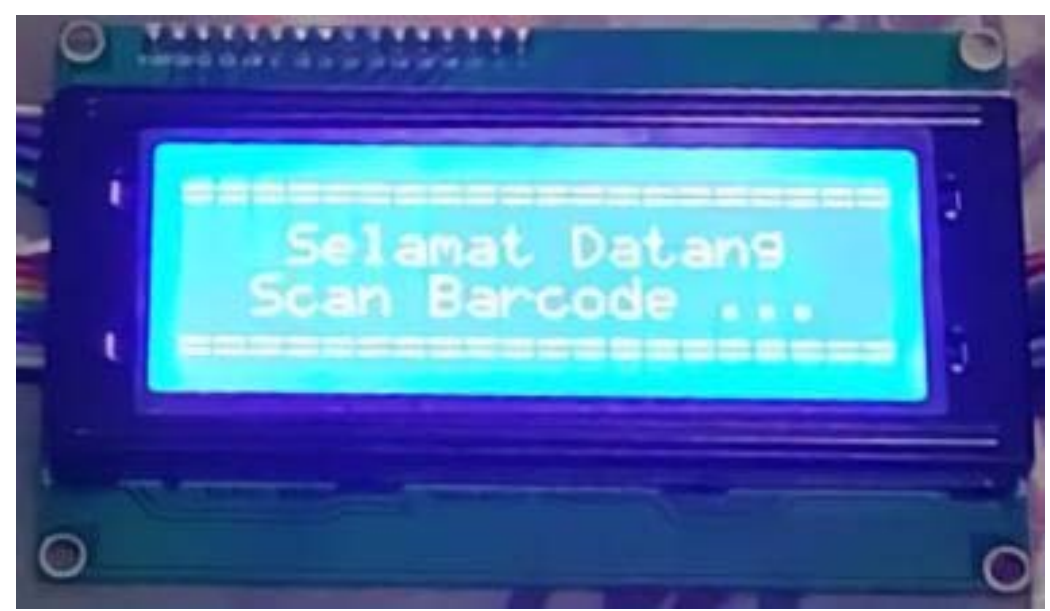

Gambar 7. Tampilan Awal Sistem

Gambar 7 menunjukan tampilan awal dari sistem parkir yang menunjukan pengendara harus menscan barcode.

Pemanfaatan Biometrics Fingerprint Sensor dan Barcode Sensor pada sistem Keaman Parkir 

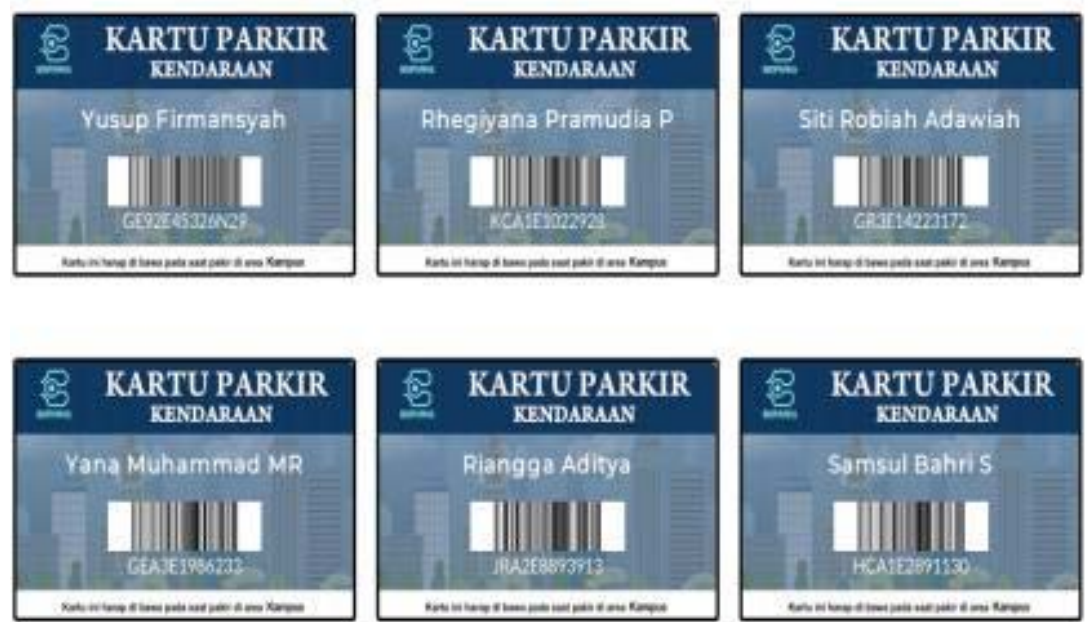

Gambar 8. Contoh Kartu Barcode

Gambar 8 adalah hasil kartu yang dicetak berisi informasi nama pemilik dan barcode tentunya. Barcode tersebut bdibuat merupakan hasil dari pengkodean dari data diri dan nomer mesin kendaraan dari pemilik kendaraan.

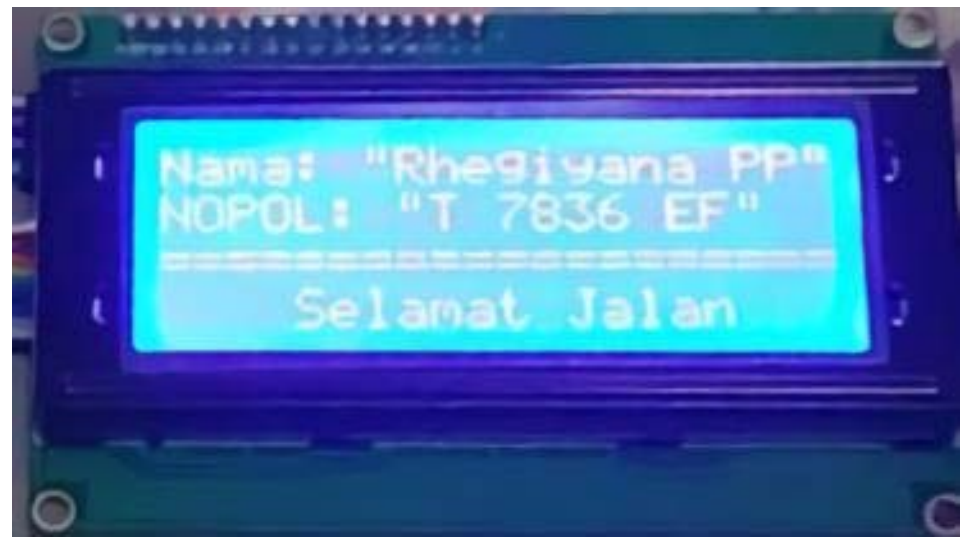

Gambar 9. Indikator Barcode Terdaftar

Pada gambar 9 menunjukan hasil pemindaian kode barcode yang sesuai dengan data yang telah terdaftar. Dari pengujian ini mendapatkan bahwa jika barocde pengendara telah terdaftar makan indikator menyala menandakan palang pintu terbuka dan pengendara masuk, selain itu data pengendara akan tersimpan.

Pada setiap gambar harus diberikan keterangan di bawah gambar. Keterangan pada tabel diberikan di atas tabel. Keterangan dituliskan dengan huruf kecil kecuali pada karakter pertama pada tiap kalimat. Seluruh gambar harus diberi penomoran secara berurutan. Gambar diletakkan di tengah halaman (center aligned), sedangkan tabel diawali di pinggir kiri (left aligned) halaman.

Tabel 1 hasil pengujian sistem parkir masuk

\begin{tabular}{|c|c|c|}
\hline No & $\begin{array}{c}\text { Hasil scan } \\
\text { Barcode }\end{array}$ & iIndikator \\
\hline 1 & $\begin{array}{c}\text { Barcode } \\
\text { terdaftar }\end{array}$ & $\begin{array}{c}\text { LED menyala } \\
\text { dan palang pintu } \\
\text { terbuka }\end{array}$ \\
\hline 2 & $\begin{array}{c}\text { Barcode tidak } \\
\text { terdaftar }\end{array}$ & $\begin{array}{c}\text { Palang pintu } \\
\text { tidak terbuka }\end{array}$ \\
\hline
\end{tabular}

Tabel 1 menunjukan hasil perbandingan antara pemilik kendaraan yang telah terdaftar sebelumnya dan pemilik kendaraan yang belum atau tidak terdaftar dalam data barcode. Tabel diatas menujukan jika pemilik kendaraan tidak terdaftar maka sistem tidak akan membua palang pintu.

Pemanfaatan Biometrics Fingerprint Sensor dan Barcode Sensor pada sistem Keaman Parkir 
2. Pengujian sistem parkir saat keluar
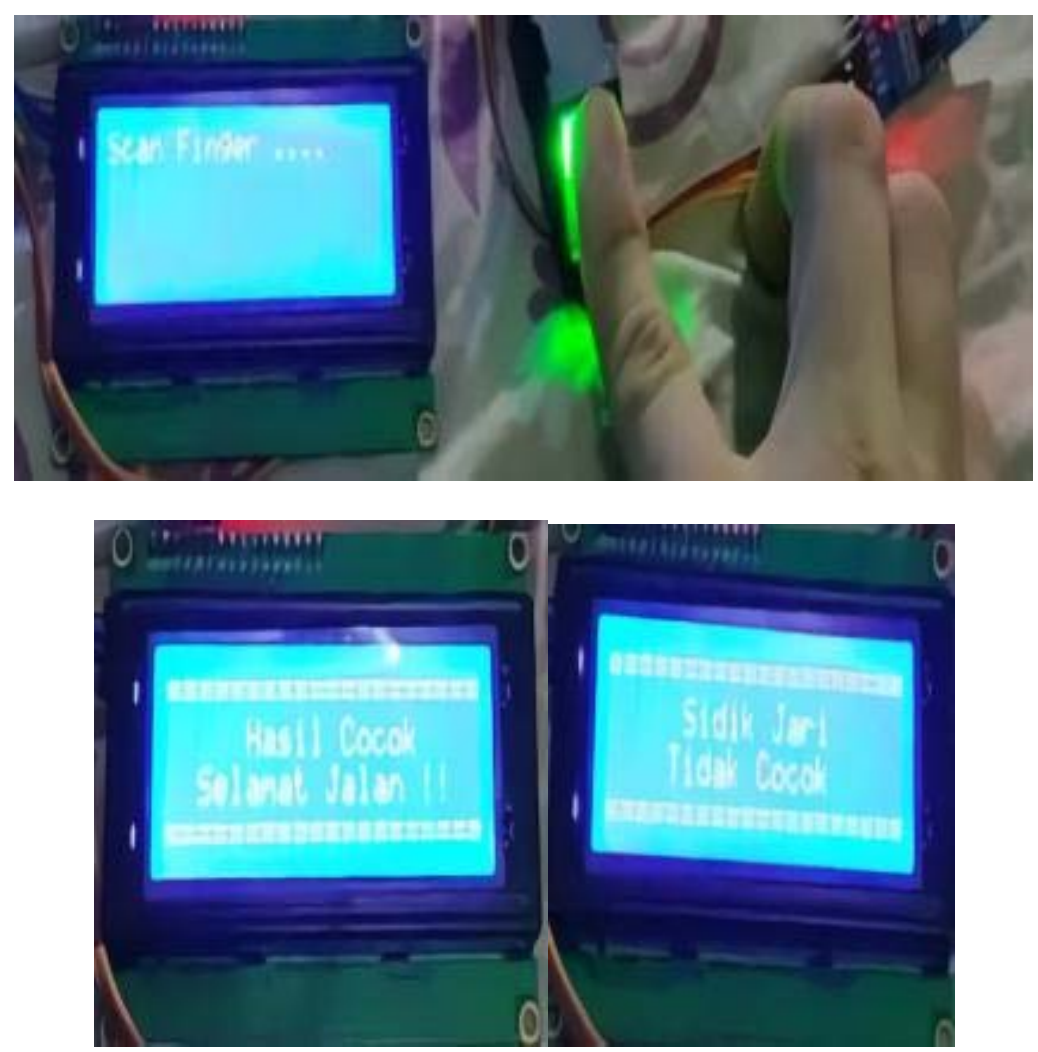

Gambar 10. Hasil validasi Barcode dan Sidik

Jari

Gambar 10 menunjukan hasil keluaran dari sistem parkir saat keluar, disini sebelum memindai sidik jari pengendara harus memvalidasi kembali barcode dan memindai barcode seperti sistem parkir saat masuk. Setekah sistem menujukan data pengendara maka lcd menunjukan pengendara diharapkan memindai sidik jari dan jika hasil nya cocok maka palang pintu akan terbuka dan pengendara dipersilahkan keluar.

Tabel 2. Kemungkinan dalam Validasi Barcode dan Sesnor Fingerprint

\begin{tabular}{|c|c|c|c|c|}
\hline \multirow{2}{*}{ no } & \multirow{2}{*}{$\begin{array}{l}\text { Percobaan } \\
\text { Barcode }\end{array}$} & \multicolumn{2}{|c|}{$\begin{array}{c}\text { Validasi } \\
\text { Fingerprint }\end{array}$} & \multirow{2}{*}{$\begin{array}{l}\text { Palang } \\
\text { pintu }\end{array}$} \\
\hline & & Terdfatar & Cocok & \\
\hline 1 & \multirow{3}{*}{ Terdaftar } & $\mathrm{Ya}$ & $\mathrm{Ya}$ & Terbuka \\
\hline 2 & & $\mathrm{Ya}$ & Tidak & $\begin{array}{l}\text { Tidak } \\
\text { Terbuka }\end{array}$ \\
\hline 3 & & Tidak & Tidak & $\begin{array}{l}\text { Tidak } \\
\text { Terbuka }\end{array}$ \\
\hline 4 & \multirow{2}{*}{$\begin{array}{l}\text { Tidak } \\
\text { terdaftar }\end{array}$} & $\mathrm{Ya}$ & Tidak & $\begin{array}{l}\text { Tidak } \\
\text { Terbuka }\end{array}$ \\
\hline 5 & & Tidak & Tidak & $\begin{array}{l}\text { Tidak } \\
\text { Terbuka }\end{array}$ \\
\hline
\end{tabular}

Dari tabel 2 menujukan validasi anatar data barcode pemilik dan data fingerprint. Dalam kemungkinan data diatas syarat membuka palang pintu harus tervalidasi antara data barcode pengendara dan data

Pemanfaatan Biometrics Fingerprint Sensor dan Barcode Sensor pada sistem Keaman Parkir 
44

p-ISSN: 1907-0012 e-ISSN : 2714-5417

fingerprint pengendara. Jika hanya salah satu yang terdaptar tetap sistem tidak akan membuka palang pintu.

3. Tampilan Aplikasi Odoo

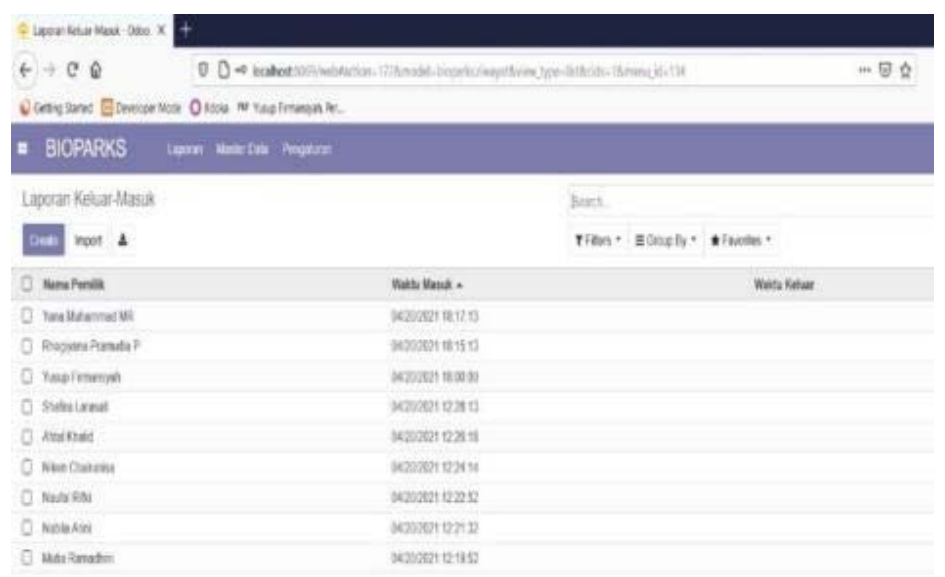

Gambar. Tampilan Utama Aplikasi Odoo

Dalam gambar 11 menunjukan tampilan awal dari aplikasi Odoo. Dapat terlihat data pengendara yang telah masuk parkiran dan keluar parkiran dengan adanya riwayat waktu keluar dan masuk.

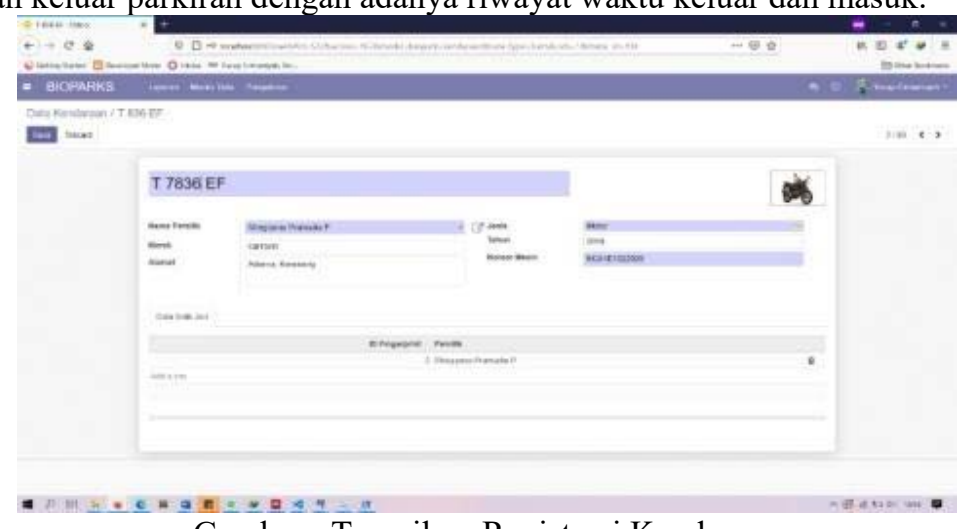

Gambar . Tampilam Registrasi Kendaraan

Gambar 12 menunjukan halaman untuk admin menginput data kendaraan dari pengendara seperrti nama, nomer polisi, nomer mesin, jenis kendaraan warna maupun type dan foto kendaraan.

Pemanfaatan Biometrics Fingerprint Sensor dan Barcode Sensor pada sistem Keaman Parkir 


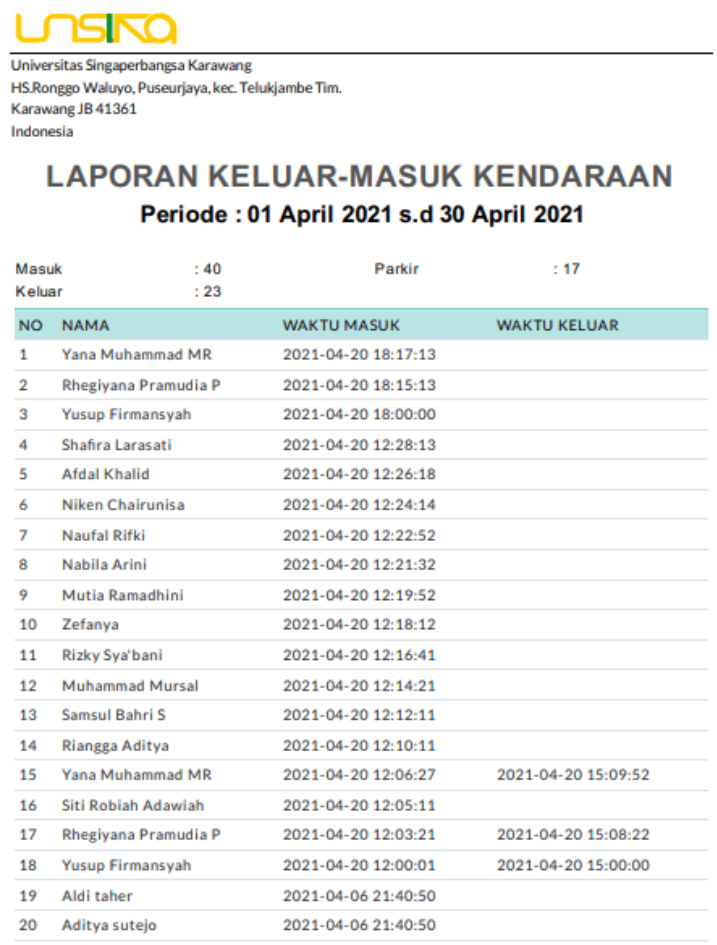

Gambar Daftar Riwayat Kendaraan

Gambar 13 diatas memperlihatkan daftar riwayat penendara perbulannya dengan demikikan mempermudah kerja dari petugas kemanan.

\section{KESIMPULAN DAN SARAN}

Berdasarkan hasil pengujian dapat diambil kesimpulan bahwa sistem parkir yang baik adalah sistem parkir yang dpat memberikan kemanan dan kenyaman bagi pemilik kendaraan. Dalam sistem BIOPARKS menggunakan teknologi yang diinginkan untuk mengurangi angka curanmor dengan menggunkan sensor barcode dan sensor fingerprint dengan validasi antara keduanya. Dengan validasi ini tingkat kemanan yang lebih tinggi karena proses pemirikasaan ganda. Dengan ada sistem BIOPARKS membuat kinerja petugas keamnan menjadi lebih praktis dan mendapatkan informasi riwayat kepemilikan kendaraan yang masuk dan keluar area parkiran.

\section{DAFTAR PUSTAKA}

[1] E. D. Widianto, H. M. Wijaya, and I. P. Windasari, "RFID Based Parking System and Vehicle Plate Number Image Recognition,” J. Teknol. dan Sist. Komput., vol. 5, no. 3, pp. 115-122, 2017, doi: 10.14710/jtsiskom.5.3.2017.115-122.

[2] A. Bachri, "Rancang Bangun Sistem Keamanan Sepeda Motor Dengan Fingerprint Berbasis Telephone," vol. 3, no. 2, p. 19, 2018.

[3] S. Amelia and I. D. Sintawati, "PENERAPAN ENTERPRISE RESOURSE PLANNING PENJUALAN AKSESORIS,” vol. 6, no. 1, pp. 69-74, 2019.

[4] M. R. Utomo, N. Karna, and R. Mayasari, "Perancangan Dan Implementasi Sistem Keamanan Parkir Dengan Fingerprint Pada Parkiran Telkom University Design and Implementation of Secured Parking Using Fingerprint in Telkom University Parking Area,” vol. 6, no. 1, pp. 980987, 2019.

[5] K. D. Dwiwahyu, Instrumentasi Sistem Keamanan Kendaraan Bermotor Menggunakan Sidik Jari Berbasis Arduino Uno, vol. 2. 2018.

[6] A. I. Legowo, "Sistem Informasi Perpustakaan Berbasis Website dengan Menggunakan Barcode Scanner pada SMK Negeri 3 Kendal," J. Univ. Dian Nuswantoro, 2014.

[7] E. Atmojo, bambang Tri; Sulistiyanti, Sri Ratna; Nasrullah, "Model Sistem Kendali Pintu Otomatis Menggunakan Barcode Berbasis PC (Personal Computer) Pada Gerbang Laboratorium Teknik Elektro Unila," Electrician, vol. 7, no. 2, pp. 47-55, 2014.

Pemanfaatan Biometrics Fingerprint Sensor dan Barcode Sensor pada sistem Keaman Parkir 
p-ISSN: 1907-0012 e-ISSN : 2714-5417

[8] B. D. Maulana et al., "Sistem Pengaturan Suhu Dan Kelembaban Kandang Ayam Menggunakan Arduino Dan Website."

[9] F. A. Deswar and R. Pradana, "MONITORING SUHU PADA RUANG SERVER MENGGUNAKAN WEMOS D1 R1 BERBASIS INTERNET OF THINGS ( IOT ),” vol. 12, no. 1, pp. 25-32, 2021.

[10] I. Dwi ariesta putri, R. R. Saenudin, and R. W. Witjaksono, "PENGEMBANGAN SISTEM ERP PURCHASE," vol. 3, no. 2, pp. 3236-3247, 2016.

Pemanfaatan Biometrics Fingerprint Sensor dan Barcode Sensor pada sistem Keaman Parkir 